\title{
Effect of the Pandemic on Students' Learning Habits in India
}

\author{
Pratiksha Bongale \\ Computer Science and Engineering \\ BIET \\ Davangere, India \\ pratiksha.bongale@bietdvg.edu \\ Sanjana R R \\ Computer Science and Engineering \\ BIET \\ Davangere, India \\ sanjanarrdvg@gmail.com
}

\author{
Chahat Tandon \\ Computer Science and Engineering \\ BIET \\ Davangere, India \\ chahat.7874@gmail.com \\ Hemant Palivela \\ Digital Analytics, eClerx LLC, \\ Austin Texas \\ hemant.datascience@outlook.com
}

\author{
Arpita T M \\ Computer Science and Engineering \\ BIET \\ Davangere, India \\ arpita.telkar@gmail.com \\ Nirmala C R \\ Computer Science and Engineering \\ BIET \\ Davangere, India \\ nirmala.cr@gmail.com
}

\begin{abstract}
The novel coronavirus has had the world on halt for a few months now. Changes in lifestyles have become a part and parcel of our daily lives, especially for students. With new teaching practices undertaken, new reforms are being made from students in kindergarten to college. This paper presents insights on the changing learning habits of Indian students' due to the hit of novel coronavirus (COVID-19). A total of 648 students from various institutes took part in the survey by responding to the questionnaires on time spent by them both for online and offline studies and others asked in closed format options. The insights are derived by comparing the performance of students based on their institute types, hours spent on self-study as well as the assistance provided by the colleges. The overall confidence in particular subjects by the end of the semester is being determined as the end result.
\end{abstract}

Keywords: COVID-19, Student learning habits, Pandemic

\section{Introduction}

The Corona pandemic started at the "wet market" in Wuhan, China became the great 2020 pandemic by March 2020. Presently there have been over 36.8 million confirmed cases and 1.07 million people have lost their lives, according to the Covid-19 dashboard recorded in October 2020. It has affected more than 199 countries and territories, with Italy, the US and Spain have had the most widespread outbreaks outside of China. India has had 6.98 million cases till date with 5,988,822 recovered patients and is growing at a rate of 70,500 more patients each day.

Are you scared yet? The coronavirus kills the immune system, affects the lungs and makes it hard to breathe. And it's spreading causing havoc all around the world. You can get it, your neighbor could get it, anyone in your office or family can get it that is if they already don't have it. It's horrifying. Scientists have stated that old people are going to get it the worst but most will get it eventually. I feel like this has always been around for over centuries. Have a glance through history, covid-19 is just a refined name. And for now, there's no specific way available to contain it. It doesn't differentiate between the rich, the young, the old, the poor, the unknown, the famous, no matter who you are, you can get it if you are not careful or even if you are. It's dangerous. People are on the edge. Locked inside houses. Border transactions are on pause. Countries have been in a state of emergency for months. Grocery stores are almost empty. Nobody is praying in the temples or churches. Stock markets have crashed. Thousands laid off work. You hope not to sneeze in public as no one is going to say god 
2

bless you anymore. The world is at halt. Coronavirus, like global warming, is a big problem of our economic structure. Although both can be classified as "environmental" or "natural" problems, they are undoubtedly socially driven. Economic contagion is spreading as fast as the coronavirus itself. Lockdowns have been initiated for months and months together. A report of the World Bank estimates the impact of a pandemic would be $22.8 \%$ percent of the GDP. India's aggressive lockdown has brought the country's growth down by $27 \%$ percent. The Prime minister of India even said that if the pandemic isn't contained, it could set us back by 21 years. Changes in lifestyles have 2 become a part and parcel of our daily lives, especially for students. With new teaching practices undertaken, new reforms are being made from students in kindergarten to college.

Talking about India, sectors like autos and pharmaceuticals were drastically led downhill due to shortage of imported components. We have started to cope up with the new normal and turned to ways in order to achieve better and hygienic lifestyles. But what about the situation of students during this time?

There is a misconception that the conventional education system in India was more focused on the marks obtained by the students in a particular subject. The skills came secondary. The reality is that schools had a contemporary relationship between the students and the teachers. The main motivation to this kind of contact or personal touch helped inculcate manners, values as well as customs and traditions. Students learnt to adapt to the surroundings and faced natural situations with their basic instincts. Talking about the new normal, the students are the future of our country. How can we let this pandemic interfere with the students' lives? As for the traditional teaching methods, the teacher centric education systems have now come to a halt. The new reforms focus more on the mastery of discipline and self-learning attitude. With online classes and exams going on, it becomes difficult to keep track of how much time each individual has started to spend online. Be it the class homework or self-study, students have started to adapt to the new norms and measures. Like every tragedy, we can let this destroy us or we can use it to our benefit and repair and even grow stronger. Be mindful. Be careful as to where we put our hands but also, where we put our attention. Our attention on the study span of our country as well.

\subsection{Terminology}

At first sight, the meaning of the words 'class homework' or "self-study" can be said to be directly correlated to college students. The colleges can be private institutes or government institutes or even international institutes. Students' learning habits depend on various factors which can't be generalized throughout the dataset. But some factors can be said to be the same like the number of siblings or resources provided. The internet connectivity also plays an important role here. Various studies on children studying habits during semester or government holidays [1] have been undertaken. The study of data based on the time spent watching TV or on similar activities increased due to house-arrest given the current coronavirus situation [2] is not surprising at all. For the students of 6th to 12th grade, the study on their behavior during the first two weeks [3] on the school holidays during Covid-19 was undertaken. The paper on working at home for school [4] at secondary grammar schools encompassed school activities as well as the social mindsets pretty accurately! Gender based homework analysis proved to give more insights than we could have imagined [5]. To get a deeper insight into what students' lives have become during the pandemic, Tran Trung et. al. [6] surveyed students in Vietnam to examine their learning habits during the time of school closures and tried figuring out answers to questions that included individual demographics - family and socioeconomic status, type of school they attended, future aspirations, hours of learning before and after lockdown, and so on.

In [8] House and J. Daniel examined the connection between instructional practices and mathematics achievement among all 13-year-old children from Chinese Taipei and found out significant connections between children's mathematics advancement and the classroom teaching practices, this too supports our research questions. They also found a heavy negative impact of usage of computers to demonstrate mathematics to students. This in accordance to what is going on in India, where many children uncomfortable with online teaching are suffering with their learning and those that are underprivileged do not even have appropriate resources to continue with their studies due to nation wide closure of educational institutions adversely impacting their future aspirations. Muhlenbruck et. al. in [10] took to highlighting the trends in the learning of the Moroccan students in the second year of college and those in the sixth year of primary school using the data in the Trends in Inter- 
national Mathematics and Science Study (TIMSS) and Progress in International Reading Literacy Study (PIRLS). In [12] the authors talk about three studies all dealing with the time duration spent by students working at home for their school work. The paper puts light on the distribution of time invested by students over the course of a week along with examining the connection between their academic achievements and the duration of time allotted by them for their school work at home. Edward A. Polloway et. al. surveyed homework methods adopted by teachers teaching students with disabilities and concluded with their survey that homework given as frequently helped students cope better with their studies in [13]. Mueller et. al. did a study on the measures of socioeconomic statuses of children in their overall development using better measures such as the Duncan Socioeconomic Index and the Siegel Prestige Scale in [26]. Evans A. S. and Julius K. M. designed a survey that brought out correlations between the student's learning habits and their academic performances to plot their learning and performance curve in [28].

In this paper, we try to gain insights on the changes in student behavior with respect to studying habits caused due to covid-19. What we mean by homework could be short term assignments, paperwork, researches, tests, preparing reports or even extensive exams. The self-study part could include things like studying for the next class or studying for the next exams, preparing for placements or quizzes or even any upcoming events. Memorizing and taking charge of one's study pattern/ habits or schedule depends on the student himself. This is a very personal choice and can't be generalized throughout the data. So, it can be said that the survey form filled by each individual can be considered to be the best method to collect data.

\subsection{Methods of Data Collection}

The method used to collect data through a survey form has proved to be very effective as the factors used for our case study are pretty personal and can be different for each individual choices or resources available. The survey encompassed questionnaires based on some general information like age group, gender, etc. Along with that, the data is divided into subsections: (a) The education institute type like government colleges (public), private or international; Subject stream and to evaluate their performance on that particular stream. (b) Number of siblings one has as well as the parents' professional background. (c) Time spent by students to attend online classes and then for self-study. This was further bifurcated as time spent studying with or without supervision. Here instructions indicate teaching or monitoring by a person or teacher themself. To compare the boost or cut down of time, the students were asked to provide the total number of hours they used to study before and during the pandemic. At the end of the survey, students had to give an overall assurance of their learning process in this pandemic. The average of each column along with standard error has been calculated to help with the computation of confidence interval range.

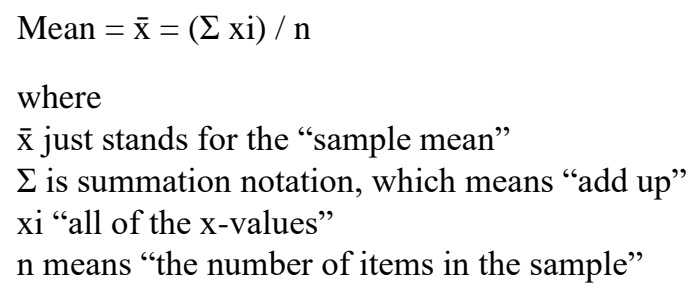

Variance $=$ The average of the squared differences from the Mean Standard Deviation is just the square root of Variance.

The Confidence Interval is based on Mean and Standard Deviation. Its formula is: 
4

$\mathrm{X} \pm \mathrm{Z} * \mathrm{~s} / \sqrt{\mathrm{n}}$

Where:

$\mathrm{X}$ is the mean

$\mathrm{Z}$ is the $\mathrm{Z}$-value from the table below

$\mathrm{s}$ is the standard deviation

$\mathrm{n}$ is the number of observations

The confidence interval has been calculated to help with further future predictions. Then at the end, the students were asked about their assurance on the learning process to ensure their confidence in themselves.

Table 1. Descriptive Statistics of Students' learning hours.

\begin{tabular}{|c|c|c|c|c|c|c|c|}
\hline \multirow{2}{*}{\multicolumn{2}{|c|}{ Learning hours }} & \multirow[t]{2}{*}{$\mathbf{N}$} & \multirow[t]{2}{*}{ Mean } & \multirow[t]{2}{*}{$\begin{array}{l}\text { Standard } \\
\text { Deviation }\end{array}$} & \multirow[t]{2}{*}{$\begin{array}{l}\text { Standard } \\
\text { error }\end{array}$} & \multicolumn{2}{|c|}{$\begin{array}{l}95 \% \text { Confi- } \\
\text { dence interval } \\
\text { for Mean }\end{array}$} \\
\hline & & & & & & $\begin{array}{l}\text { Lower } \\
\text { bound }\end{array}$ & $\begin{array}{l}\text { Upper } \\
\text { bound }\end{array}$ \\
\hline \multirow[t]{2}{*}{ Gender } & Male & 373 & \multirow[t]{2}{*}{0.424} & \multirow[t]{2}{*}{0.494} & \multirow[t]{2}{*}{0.0194} & \multirow[t]{2}{*}{0.386} & \multirow[t]{2}{*}{0.462} \\
\hline & Female & 275 & & & & & \\
\hline Standard & $\begin{array}{c}\text { Collage } \\
(1 \mathrm{st} / 2 \mathrm{nd} / 3 \mathrm{rd} / 4 \mathrm{th})\end{array}$ & 648 & 1.958 & 0.266 & 0.0104 & 1.937 & 1.978 \\
\hline \multirow[t]{3}{*}{ Institute Type } & Public & 137 & \multirow[t]{3}{*}{0.7978} & \multirow[t]{3}{*}{0.424} & \multirow[t]{3}{*}{0.0166} & \multirow[t]{3}{*}{0.765} & \multirow[t]{3}{*}{0.830} \\
\hline & Private & 505 & & & & & \\
\hline & International & 6 & & & & & \\
\hline \multirow[t]{5}{*}{ Subject } & Science & 141 & \multirow[t]{5}{*}{2.222} & \multirow[t]{5}{*}{1.240} & \multirow[t]{5}{*}{0.0487} & \multirow[t]{5}{*}{2.126} & \multirow[t]{5}{*}{2.317} \\
\hline & Arts & 14 & & & & & \\
\hline & Commerce & 58 & & & & & \\
\hline & Technical & 430 & & & & & \\
\hline & Medical & 5 & & & & & \\
\hline \multirow{4}{*}{$\begin{array}{c}\text { Self-evaluation } \\
\text { of Academic } \\
\text { performance }\end{array}$} & Below Average & 19 & \multirow[t]{4}{*}{1.663} & \multirow[t]{4}{*}{0.679} & \multirow[t]{4}{*}{0.0266} & \multirow[t]{4}{*}{1.611} & \multirow[t]{4}{*}{1.715} \\
\hline & Average & 238 & & & & & \\
\hline & Good & 333 & & & & & \\
\hline & Excellent & 58 & & & & & \\
\hline \multirow{2}{*}{$\begin{array}{l}\text { Learning time before } \\
\text { Covid-19 }\end{array}$} & Less than 4 hours & 429 & \multirow[t]{2}{*}{0.370} & \multirow[t]{2}{*}{0.546} & \multirow[t]{2}{*}{0.0214} & \multirow[t]{2}{*}{0.328} & \multirow[t]{2}{*}{0.412} \\
\hline & $4-7$ hours & 198 & & & & & \\
\hline
\end{tabular}




\begin{tabular}{|c|c|c|c|c|c|c|c|}
\hline & Above 7 hours & 21 & & & & & \\
\hline \multirow{3}{*}{$\begin{array}{l}\text { Learning time during } \\
\text { covid }\end{array}$} & Less than 4 hours & 352 & \multirow[t]{3}{*}{0.530} & \multirow[t]{3}{*}{0.630} & \multirow[t]{3}{*}{0.0247} & \multirow[t]{3}{*}{0.482} & \multirow[t]{3}{*}{0.579} \\
\hline & $4-7$ hours & 248 & & & & & \\
\hline & Above 7 hours & 48 & & & & & \\
\hline \multirow{3}{*}{$\begin{array}{l}\text { Online learning time } \\
\text { during covid }\end{array}$} & Less than 4 hours & 159 & \multirow[t]{3}{*}{0.882} & \multirow[t]{3}{*}{0.6002} & \multirow[t]{3}{*}{0.0235} & \multirow[t]{3}{*}{0.836} & \multirow[t]{3}{*}{0.929} \\
\hline & $4-7$ hours & 406 & & & & & \\
\hline & Above 7 hours & 83 & & & & & \\
\hline \multirow{3}{*}{$\begin{array}{l}\text { Online learning with } \\
\text { instructions/ teaching }\end{array}$} & Less than 4 hours & 180 & \multirow[t]{3}{*}{0.7839} & \multirow[t]{3}{*}{0.541} & \multirow[t]{3}{*}{0.0212} & \multirow[t]{3}{*}{0.742} & \multirow[t]{3}{*}{0.825} \\
\hline & $4-7$ hours & 428 & & & & & \\
\hline & Above 7 hours & 40 & & & & & \\
\hline \multirow{3}{*}{$\begin{array}{l}\text { Online learning with- } \\
\text { out instructions/ } \\
\text { teaching }\end{array}$} & Less than 4 hours & 477 & \multirow[t]{3}{*}{0.305} & \multirow[t]{3}{*}{0.544} & \multirow[t]{3}{*}{0.0213} & \multirow[t]{3}{*}{0.263} & \multirow[t]{3}{*}{0.347} \\
\hline & $4-7$ hours & 144 & & & & & \\
\hline & Above 7 hours & 27 & & & & & \\
\hline \multirow{3}{*}{$\begin{array}{l}\text { Offline learning time } \\
\text { during covid }\end{array}$} & Less than 4 hours & 520 & \multirow[t]{3}{*}{0.2391} & \multirow[t]{3}{*}{0.515} & \multirow[t]{3}{*}{0.0202} & \multirow[t]{3}{*}{0.199} & \multirow[t]{3}{*}{0.278} \\
\hline & $4-7$ hours & 110 & & & & & \\
\hline & Above 7 hours & 23 & & & & & \\
\hline \multirow{3}{*}{$\begin{array}{l}\text { Offline learning with } \\
\text { instructions/teaching }\end{array}$} & Less than 4 hours & 515 & \multirow[t]{3}{*}{0.2407} & \multirow[t]{3}{*}{0.504} & 0.0198 & 0.201 & 0.279 \\
\hline & $4-7$ hours & 110 & & & & & \\
\hline & Above 7 hours & 23 & & & & & \\
\hline Offline learning & Less than 4 hours & 519 & 0.228 & 0.485 & 0.0190 & 0.190 & 0.265 \\
\hline tions/teaching & $4-7$ hours & 110 & & & & & \\
\hline & Above 7 hours & 19 & & & & & \\
\hline I can assure my learn- & Strongly Disagree & 30 & 2.58 & 0.928 & 0.0364 & 2.513 & 2.656 \\
\hline & Disagree & 44 & & & & & \\
\hline & Neither agree nor & 157 & & & & & \\
\hline
\end{tabular}




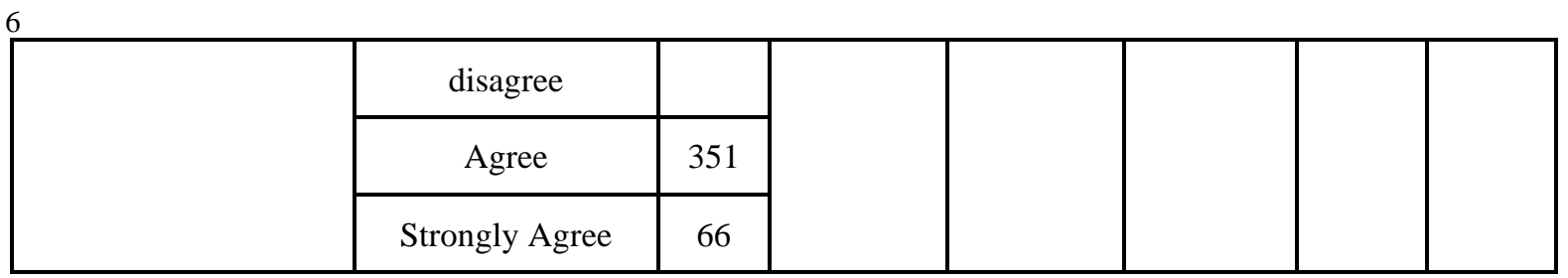

*Learning hours in Table 1 indicate the number of hours students of various age groups invest in studying at home during the pandemic.

\subsection{Aims - Hypothesis}

The present study aims to analyze different situations and factors affecting the students of India based on a survey conducted for college(public/private/international) students. We aim to carry out the research based on the following questions in particular:

1. How much time did students invest studying before and during Covid-19? The time students put in to develop on an educational level while taking up industry-ready approaches on an average day depends on the type of surroundings they are exposed to.

Hypothesis 1- Students spending less time on studies while attending live classes get more time to selfstudy during online classes as the buffer time of transportation, dressing up etc., is saved and put to better use.

2. What was the average performance of the students studying in different institutes (public, private, international) before COVID? The performance of the students depends upon the time they spend on their studies and understanding.

Hypothesis 2- Performance of the students studying in private and international institutes will be more compared to those who are studying in public. Most private and international institutes assist their students with good resources for instance teaching, guidance, students tend to spend much time on their campus. The performance of the students directly impacts the college score. So, we hypothesized that the performance of students studying in international or private will be high.

3. How much time do students spend in online and offline teaching during the pandemic comparing on institution type? Everything is shut down in this pandemic, so schools and colleges teaching has shifted towards online teaching.

Hypothesis 3- Since the performance of the students' matters for the institutions, students of international institutes spend much time studying either online or offline.

4. What kind of institutes were able to provide better offline/online assistance to the students during the pandemic? With the given situation, public/ private and international institutes are expected to take the required measures to make the students' lives easy and understanding of the subject better.

Hypothesis 4- As remote teaching/classes are becoming the new normal, students must be provided with the required resources and assistance in order to gain as much information as they can. As public institutes have limited teaching hours, they are not expected to provide the required experience. On the other hand, international and private institutes must cope up as they are not government funded but by the people.

5. How are students assured about their learning process in current situations? If students get proper assistance from their respective institutes then they will be capable of performing well in upcoming exams. Hypothesis 5- Students whose performance is good or excellent are likely to be confident about their learning process. Students from technical backgrounds having practical subjects are likely to disagree with their learning process because they need physical classes for conducting experiments and better understanding. 


\section{$2 \quad$ Method}

\subsection{Design}

The paper presents various comparisons based on the data collected via survey performed in order to gain insights on how effective the online reforms have been.

Let's take an example. There are two students, 'student A' and 'student B'. Student A studies in a public institute studying Computer science. Whereas, B is a student of an international institute studying Computer science. A studies for 4-7 hours every day offline but less than 4 or sometimes none at all online due to network issues. B on the other hand, studies for less than 4 hours online and offline combined. Which one do you think would be able to give better assurance of his/her performance at the end of the semester?

\subsection{Our Study}

Our study includes a real time survey based on the new challenges faced by students of public/ private as well as international college students in regard to their overall educational development and performance during the pandemic. The results in our study have come to prove the different situations and pitfalls of our education system based on the educational institute type as well as the individual's performance and urge to learn. As for the situation of student A and B mentioned above, our study has proved that student A would be provided with limited assistance as the college has limited staff working hours whereas B is provided with maximum assistance overall. But just the assistance wouldn't make a difference unless the student is ready to put in efforts on his/her own. Keeping that in mind the performance of both A and B can be determined. A 6 can be assumed to have better performance as compared to B. The graphs below give a detailed analysis and help prove the same.

\subsection{Data Analysis}

A survey containing questions on the factors like education, study hours, performance etc. recorded 648 responses by college students. Out of 648 responses, 373 students were male and remaining were female students. Before the pandemic about $66 \%$ in overall count used to study for less than 4 hours, whereas $30 \%$ studied for 4 7 hours and only $4 \%$ studied for more than 7 hours. As per the data when the pandemic hit, there was an upsurge in the number of hours students used to study before covid-19. During covid about $8 \%$ students switched their study time from less than 4 hours to 4-7 hours and about $4 \%$ more students switched for above 7 hours study time. In terms of subject stream of the students, $21 \%$ of them were from Science background, 2\% from Arts, $9 \%$ from Commerce, $66 \%$ Technical and remaining from Medical background. When analyzed the student's performance on their respective streams, $9 \%$ of the 648 students are excellent, $51 \%$ are good at their respective subjects, $36 \%$ are moderate and remaining students' performance is not so good towards their subject group. When students were asked about their current learning process, $10 \%$ of the students are very much confident about it, whereas the majority of $54 \%$ are somewhat confident, $24 \%$ are uncertain about their assurance on the subject and remaining students are insecure about it. 


\section{$3 \quad$ Results and Analysis}

\subsection{How much time did the students invest studying before and during Covid-19?}
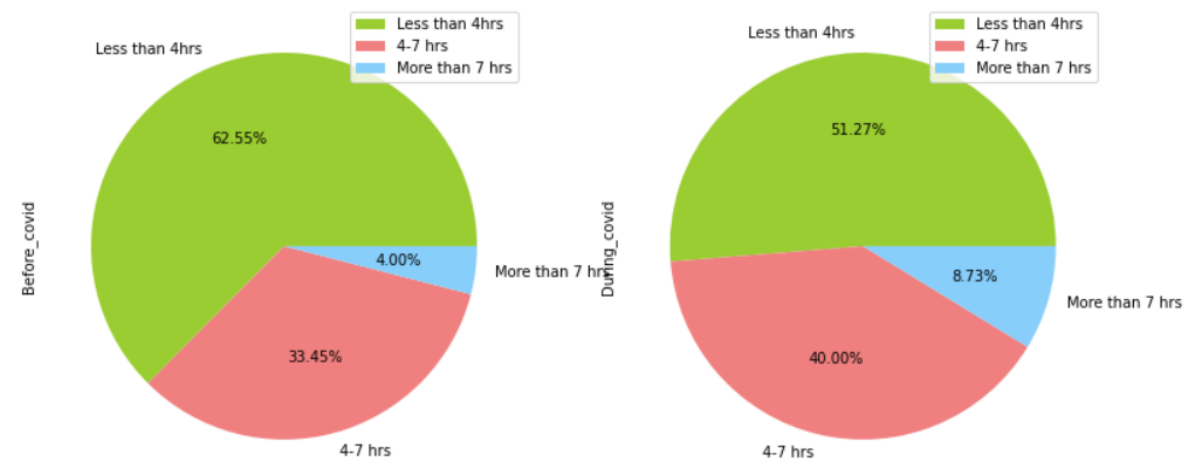

Fig. 1. Time invested by students in studies before/during covid

During covid-19, about $62.55 \%$ students studied for 4-7 hours per day, 33.45\% studied for 4-7 hours and only 4\% studied for more than 7 hours. Whereas during the pandemic, due to reforms made such as online classes and with the added self-study time, the number of students studying for more than 7 hours increased by $5 \%, 7 \%$ increase was observed for the 4-7-hour interval and about $12 \%$ decrease in less than 4 hours interval. Hence hypothesis- 1 was proved to be true.

\subsection{What was the average performance of students studying in different institutes (public, private,} international) before COVID?

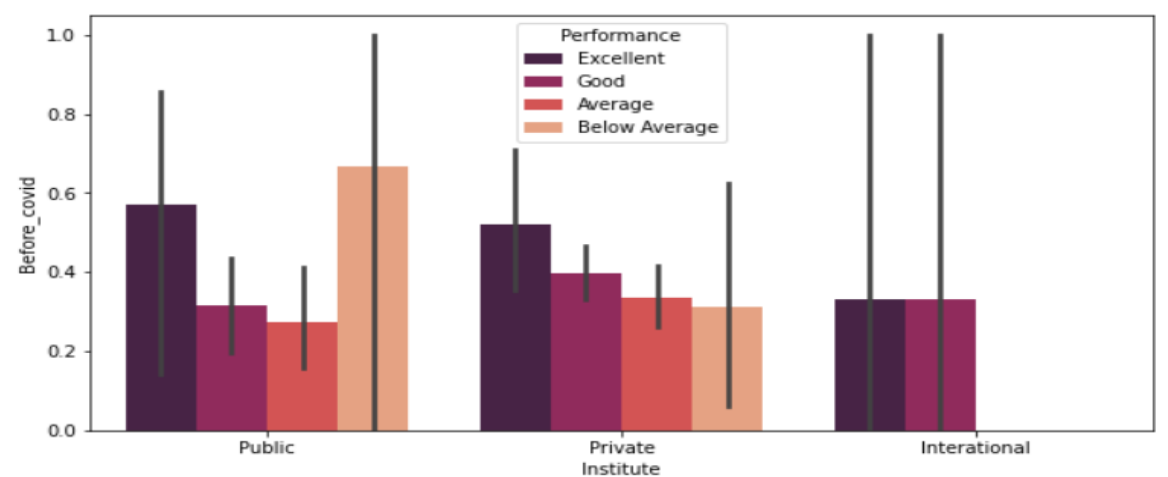

Fig. 2. Performance measure before covid

It is clear that students of international institutes are confident in themselves about their performance evaluating as excellent and good on the respective streams. But wherein public institutes most of the students evaluated their performance as below average overall. This might be because of the assistance provided by government institutes is low compared to private and international and also the students of public institutes might lack necessary resources. Hypothesis 2 holds true according to the fig 2. 
3.3 How much time do students spend in online and offline teaching during the pandemic? Compare on the institution type.

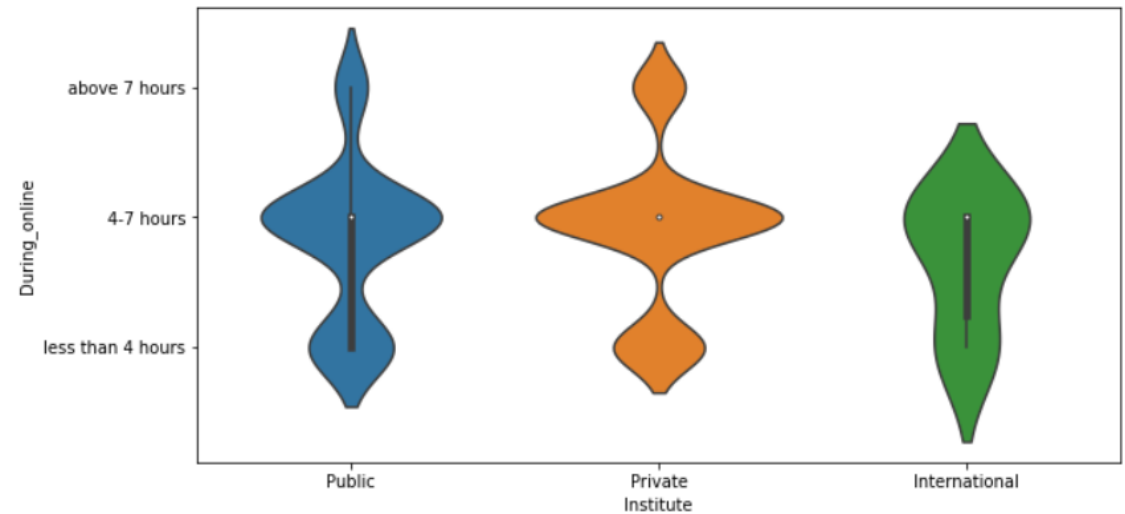

Fig. 3. Time spent by students (online)

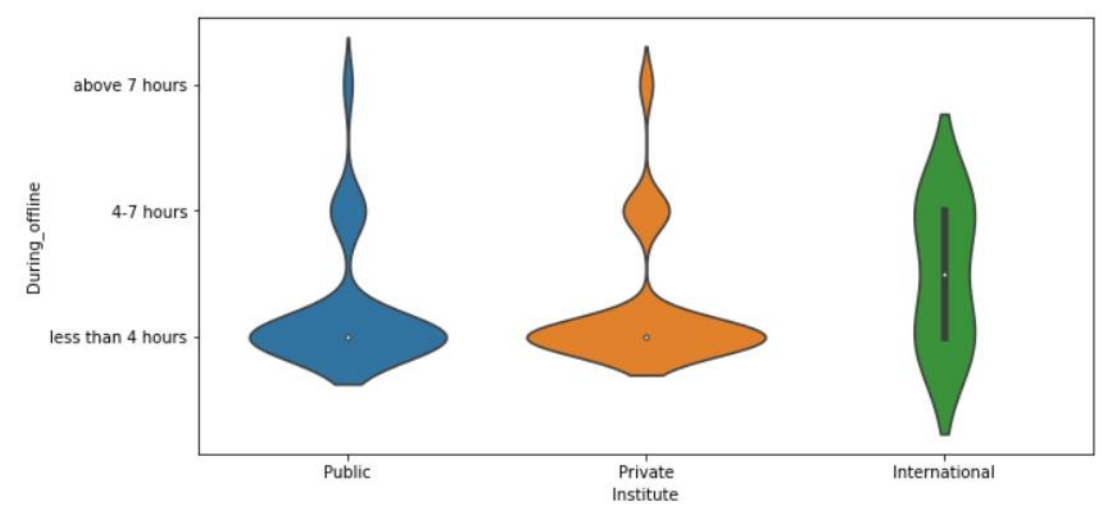

Fig. 4. Time spent by students (offline)

As per the analysis, most of the students of private institutes tend to spend 4-7 hours for online studies and less than 4 hours for offline studies including with and without teachers' instructions during pandemic. When it comes to international institutes, students spend at most 7 hours for both online and offline not more than that. Most of the students of both public and private institutes spend less than 4 hours when it comes to offline studies. As hypothesized before in hypothesis 3 that students from international institutes tend to spend more time in studies both online and offline but it turned out to be students of private institutes spend more time in studies. The plot implies that the private institutes' online assistance is better than when compared to public institutes. 
10

3.4 What kind of institutes were able to provide better offline / online assistance to the students during the pandemic?

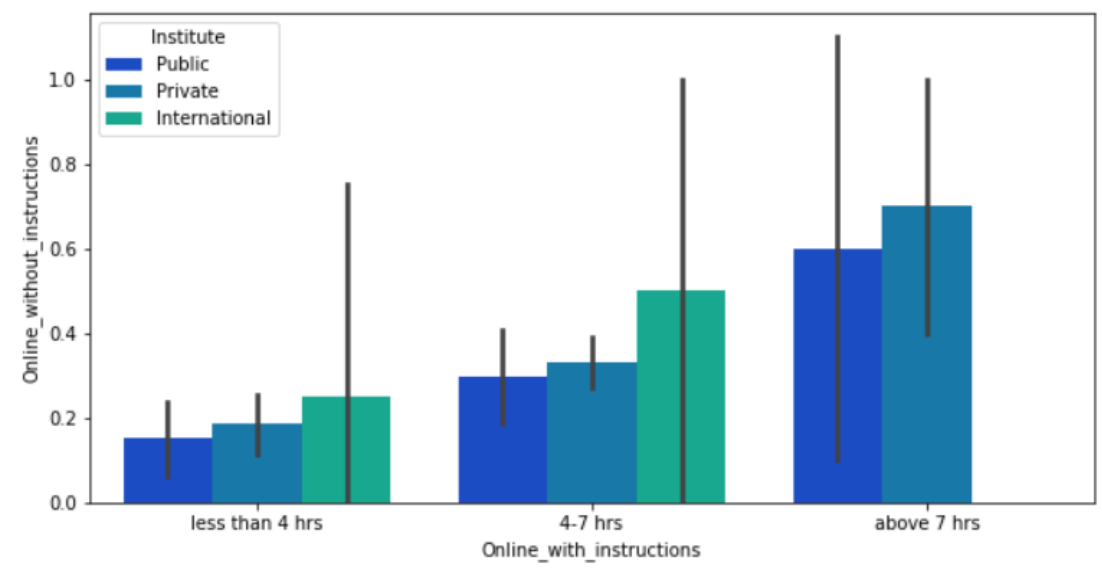

Fig. 5. Online assistance provided by institues

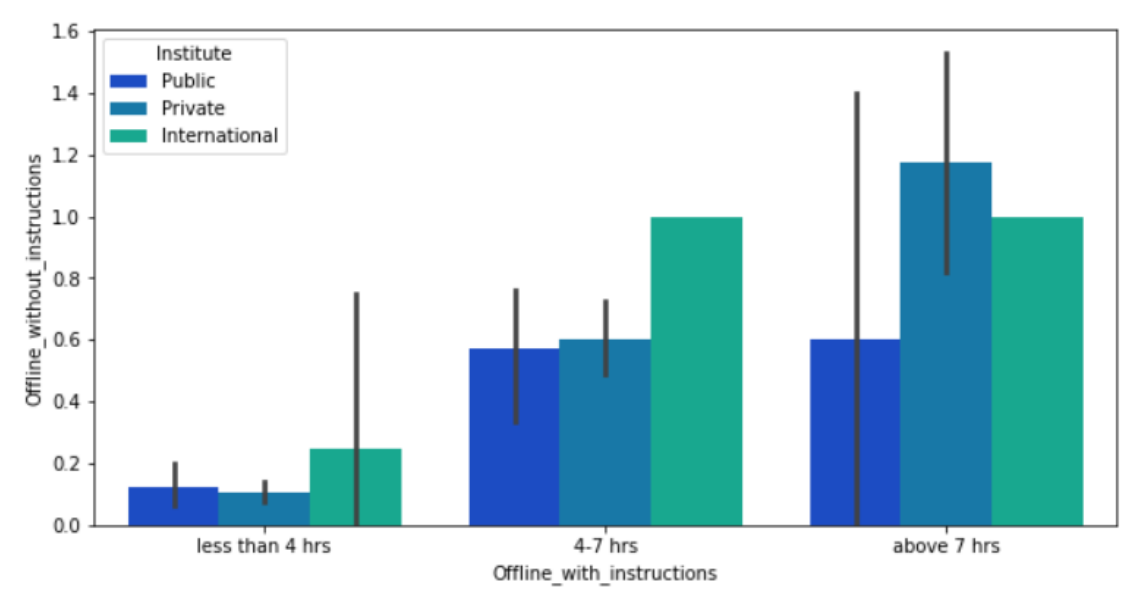

Fig. 6. Offline assistance provided by institutes

Public institutes get findings from the government whereas private institutes charge students directly. International colleges are known to provide utmost attention to students and are expected to deal with any types of problems more effectively as compared to private or public institutes. The above-mentioned graphs prove that international institutes have provided the most guidance to its students keeping in mind the hardships of the present day-to-day lives. Along with the 4 to 7 -hour online guidance, students were provided with a lot of offline instructions as well. Whereas the public and private institutes fail to provide a lot of 8 assistance when it comes to offline teaching. This could be due to limited teaching hours allotted to the faculty. 


\subsection{How are students assured about their learning process in the current situation?}

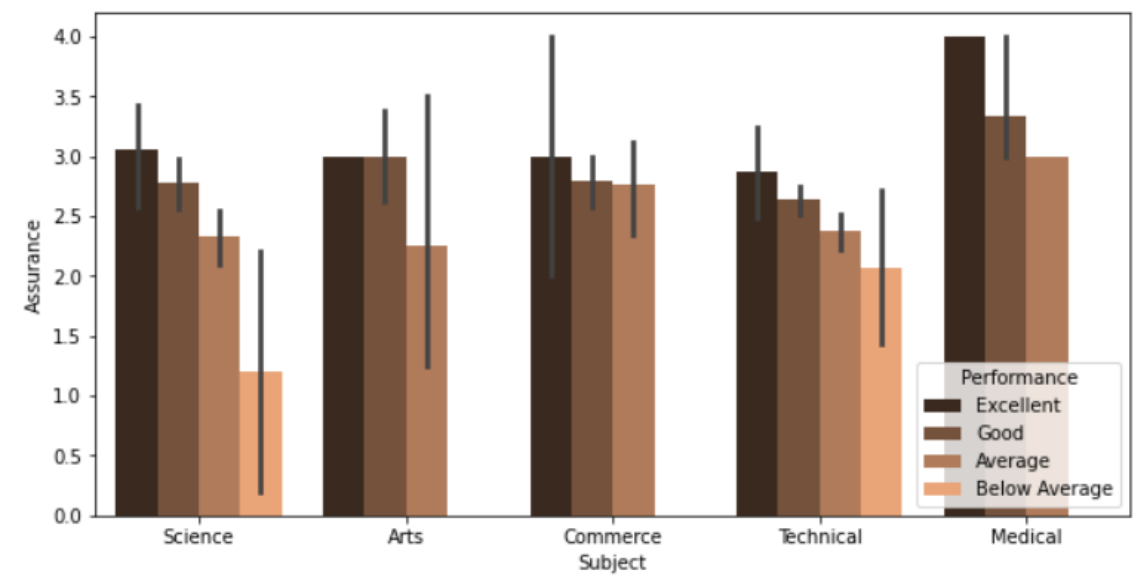

Fig. 7. Current Performance status

When compared between the subject streams on performance and assurance, students of medical background are much confident about their performance and strongly agree with their current learning process during COVID. Whereas none of the students from other backgrounds besides medical strongly agree on their learning and somewhere lack their confidence. Majorly, students of technical backgrounds' performance are below average and they neither agree nor disagree with their learning process. This may be due to major technical subjects being practical like in civil branch or mechanical. But due to covid it is not possible to conduct physical sessions for these branches which results the students lose confidence in themselves by this hypothesis 5 holds true.

\section{Conclusion}

This paper focuses on the impact of the pandemic on students' study routine. As per the analysis, students are spending more time studying in the current situation when compared to that of before pandemic. The performance of the students from international institutes was comparatively better than that of the students from private and public colleges as they spent a moderate amount of time before covid. The overall study time seems to have increased as the buffer time on live classes has been cut down due to remote availability. Students from technical backgrounds having practical subjects are under confident about their learning process in the current situation of COVID.

\section{References}

1. Novel Coronavirus Information Center.

2. V. La, T. Pham, T.M. Ho, N.M. Hoàng, N.P.K. Linh, T. Vuong, ... Q. Vuong, Policy response, social media and science journalism for the sustainability of the public health system amid COVID-19 outbreak: The Vietnam lessons, Sustainability 12 (2020) 2931

3. World Health Organization. A Coordinated Global Research Roadmap; World Health Organization: Geneva, Switzerland, 2020. 
4. Cooper, H., Lindsay, J. J., Nye, B., \& Greathouse, S. (1998). Relationships among attitudes about homework, amount of homework assigned and completed, and student achievement. Journal of Educational Psychology, 90, 70e83.

5. Vietnam Ministry of Education and Training (2020). Official Letter No. 793 / BGDĐT-GDTrH dated $12 / 3 / 2020$ about enhancing teaching via the internet and on television during the time of absence from school to prevent and control Covid-19.

6. Anh-Duc Hoang, Yen-Chi Nguyen, Viet-Hung Dinh, Hiep-Hung Pham, Dataset of Vietnamese Student's Learning Habit during School Closure due to COVID-19 Pandemic, Mendeley Data (2020) v3.

7. Wagner, P., Schober, B., \& Spiel, C. (2005). Wer hilft beim Lernen für die Schule? Soziales Lernumfeld in Hauptschule und Gymnasium [Who helps learning for school? Social learning environment at secondary and grammar schools]. Zeitschrift fur Entwicklungspsychologie und Pädagogische Psychologie, 37, $101 \mathrm{e} 109$.

8. House, J. D. (2002). Instructional practices and mathematics achievement of adolescent students in Chinese Taipei: results from the TIMSS 1999 assessment. Child Study Journal, 32, 157e178.

9. Schmitz, B., \& Skinner, E. (1993). Perceived control, effort, and academic performance: interindividual, intraindividual, and multivariate time series analysis. Journal of Personality and Social Psychology, 64, $1010 \mathrm{e} 1028$.

10. Muhlenbruck, L., Cooper, H., Nye, B., \& Lindsay, J. J. (2000). Homework and achievement: explaining the different strengths of relation at the elementary and secondary school levels. Social Psychology of Education, 3, $295 \mathrm{e} 317$.

11. Oswald-Ulreich, P. S. (1997). Die Hausaufgaben Problematik [The homework problem]. Unpublished Dissertation, University of Vienna, Austria.

12. Pakulla, R. (1967). Hausaufgaben e Empfehlungen für Lehrer und Erzieher [Homework e Recommendations for teachers and educators]. Netzschkau, Germany: VEB Buch.

13. Polloway, E.-A., Epstein, M.-H., Bursuck, W.-D., \& Jayanthi, M. (1994). Homework practices of general education teachers. Journal of Learning Disabilities, 27, 500e509.

14. Schmitz, B., \& Skinner, E. (1993). Perceived control, effort, and academic performance: interindividual, intraindividual, and multivariate time series analyses. Journal of Personality and Social Psychology, 64, $1010 \mathrm{e} 1028$.

15. Schober, B. (2003). O”kologische Validità"t [Ecological validity]. In K. D. Kubinger, \& R. S. Ja"ger (Eds.), Schlüsselbegriffe der psychologischen

16. Diagnostik (pp. 310e312). Weinheim, Germany: Beltz. Schober, B., Reimann, R., \& Wagner, P. (2004). Is research on gender-specific underachievement in gifted girls an obsolete topic? New findings onan often discussed issue. High Ability Studies, 15, 43e62.

17. Smith, T.-E. (1990). Time and academic achievement. Journal of Youth and Adolescence, 19, 539e558.Spiel, C., Wagner, P., \& Fellner, G. (2002). Wie lange arbeiten Kinder zu Hause für die Schule? Eine Analyse in Gymnasium und Grundschule [How long and for what subjects do pupils work at home for school? An analysis of academic secondary school and primary school]. Zeitschrift für Entwicklungspsychologie und Pädagogische Psychologie, 34, 125e135.

18. Trautwein, U., \& Ko"ller, O. (2003). The relationship between homework and achievement e still much of a mystery. Educational Psychology Review, 15, 115e145. 10

19. Trautwein, U., Ko“ller, O., Schmitz, B., \& Baumert, J. (2002). Do homework assignments enhance achievement? A multilevel analysis in 7thGrade Mathematics. Contemporary Educational Psychology, 27, $26 \mathrm{e} 50$.

20. Tymms, P., \& Fitz-Gibbon, C. T. (1992). The relationship of homework to A-level results. Educational Research, 34, 3e10.

21. Vetter, W. (1983). Hausaufgaben und Freizeit von Gymnasiasten [Homework and leisure time among academic secondary school students]. Die Schulfamilie: Zeitschrift für Elternhaus und Gymnasium, 32, $164 \mathrm{e} 171$.

22. Wagner, P., Schober, B., \& Spiel, C. (2005). Wer hilft beim Lernen fur die Schule? Soziales Lernumfeld in Hauptschule und Gymnasium [Who helps learning for school? Social learning environment at secondary and grammar schools]. Zeitschrift für Entwicklungspsychologie und Pa"dagogische Psychologie, 37, $101 \mathrm{e} 109$.

23. Wagner, P., \& Spiel, C. (1999). Arbeitszeit für die Schule e Zu Variabilita“t und Determinanten [The amount of time pupils work for school evariability and determinants]. Empirische Pa"dagogik, 13, 123e150. 
24. Xu, J. (2006). Gender and homework management reported by high school students. Educational Psychology, 26, 73e91.

25. Anh-Duc Hoang, Yen-Chi Nguyen, Viet-Hung Dinh, Hiep-Hung Pham, Dataset of Vietnamese Student's Learning Habit during School Closure due to COVID-19 Pandemic, Mendeley Data (2020) v3http://dx.doi.org/10.17632/2pzvmnb2km.3.

26. C.W. Mueller, T.L. Parcel, Measures of socioeconomic status: Alternatives and recommendations, Child Development 52 (1) (1981) 13-30.

27. R.M. Hauser, Measuring socioeconomic status in studies of child development, Child Development 65 (6) (1994) 1541-1545.

28. E.A. Siahi, J.K. Maiyo, Study of the relationship between study habits and academic achievement of students: A case of Spicer Higher Secondary School, India, International Journal of Educational Administration and Policy Studies 7 (7) (2015) 134-141.

29. R.B. McNeal Jr, Differential effects of parental involvement on cognitive and behavioral outcomes by socioeconomic status, The Journal of Socio-Economics 30 (2) (2001) 171-179.

30. J.S. Coleman, Social capital in the creation of human capital, American Journal of Sociology 94 (1988) S95-S120.

31. Henderson, A. T. (1987). The Evidence Continues to Grow: Parent Involvement Improves Student Achievement. An Annotated Bibliography. National Committee for Citizens in Education Special Report. https://eric.ed.gov/?id=ED315199.

32. D.H. Schunk, Goal setting and self-efficacy during self-regulated learning, Educational Psychologist 25 (1) (1990) 71-86.

33. W.S. Grolnick, M.L. Slowiaczek, Parents' involvement in children's schooling: A multidimensional conceptualization and motivational model, Child Development 65 (1) (1994) 237-252.

34. D.J. Shernoff, M. Csikszentmihalyi, B. Schneider, E.S. Shernoff, Student engagement in high school classrooms from the perspective of flow theory, Applications of flow in human development and education, Springer, Dordrecht, 2014, pp. 475-494.

35. B. Poellhuber, M. Chomienne, T. Karsenti, The effect of peer collaboration and collaborative learning on selfefficacy and persistence in a learner-paced continuous intake model, Journal of Distance Education 22 (3) (2008) 41-62. 